\title{
Effect of Different Doses of Vanadium on Yield Attributing Characters of Sweet Corn (Zea mays L.)
}

\author{
Akshay S. Magar ${ }^{1}$, Pragati Misra², M.B. Latke ${ }^{3}$, \\ Pradeep Kumar Shukla ${ }^{1^{*}}$ and P.W. Ramteke ${ }^{1}$
}

${ }^{1}$ Department of Biological Sciences, Faculty of Science, Sam Higginbottom University of Agriculture, Technology and Sciences, Allahabad 211007, UP, India

${ }^{2}$ Department of Molecular and Cellular Engineering, Jacob School of Biotechnology and Bioengineering, Sam Higginbottom University of Agriculture, Technology and Sciences, Allahabad 211007, UP, India

${ }^{3}$ Department of Genetics and Plant Breeding, Naini Agriculture Institute, Sam Higginbottom University of Agriculture, Technology and Sciences, Allahabad 211007, UP, India

*Corresponding author

\section{A B S T R A C T}

\section{Keywords}

Vanadium, Sweet corn, Growth, Yield characters

Article Info

Accepted:

17 July 2018

Available Online:

10 August 2018
A pot experiment was conducted in the Department of Biological Sciences at SHUATS Allahabad during rabi session 2017-2018 to study the effect of different concentration of vanadium $(0,20 \mathrm{ppm}, 40 \mathrm{ppm}, 60 \mathrm{ppm}, 80 \mathrm{ppm}, 100 \mathrm{ppm})$ on two variety of sweet corn (Zea mays L.) Madhuri \& PhuleMadhu. Vanadium was applied mode of application at 30 DAS and flowering time. The observation was recorded at harvesting time. It was shows that maximum production observed in variety Madhuri in $\mathrm{T}_{2}(20 \mathrm{ppm})$ compared to control. Minimum production shows variety Phule Mahu (100ppm) compared to control. Vanadium applied to plant in low concentrate resulted in improvement of yield of sweet

\section{Introduction}

Sweet corn (Zea mays L.) is the world's most widely cultivated food crop. It is a member of family Gramineae (Poaeceae) sub family Panicoideae. Maize is known as 'Queen of cereals' and 'King of fodder'. Sweet corn is a hybridized variety of maize specifically breeds to increase the sugar content. Its consumption at immature stage as roasted and boiled ears is a popular practice as the kernels are sweet (content $12-20 \%$ sugar), creamy, tender and crispy. After harvesting green cobs, the plants of sweet corn are used as green fresh or dry fodder. This speciality corn with its high market value is gaining popularity and now a day's its cultivation is the first choice of the farmers (Suthar et al., 2014).

Sweet corn is a new choice of the progressive farmers as its green cobs as well as nutritious green fodder fetch higher market prices (Painyuli et al., 2013). It is gaining popularity both in rural and urban areas because of its 
higher sugar and low starch content and delicious (Singh et al., 2012). Corn is one of the most important food resources of human and as a $\mathrm{C}_{4}$ crop absorbs high amounts of nutrients from the soil. The important feature of this plant's growth is efficiency of micro elements in various conditions of soils (Safyan, 2012).

Micronutrients play an active role in the plant metabolism process starting from cell wall development to respiration, photosynthesis, chlorophyll formation, enzyme activity nitrogen fixation and reduction (Adhikary et al., 2010). Vanadium (V) is a transition element widely distributed in nature and biological systems, as well as a part of fossil fuels, and agricultural supplies, such as chemical fertilizers which contain ammonium metavanadate $\left(\mathrm{NH}_{4} \mathrm{VO}_{3}\right)$ (Hector et al., 2017).

$\mathrm{V}$ is the $5^{\text {th }}$ most abundant element among the transitional metals in the earth crust. $\mathrm{V}$ is extensively dispersed in the environment by different ways like leaching, combustion, use of fertilizers, and waste material from industries, resultantly; $\mathrm{V}$ contaminates the soil, water and atmosphere. The most common form of vanadium is Vanadium pentaoxide $\left(\mathrm{V}_{2} \mathrm{O}_{5}\right)$, followed by ammonium metavanadate $\left(\mathrm{NH}_{4} \mathrm{VO}_{3}\right)$ and sodium orthovanadate $\left(\mathrm{NaH}_{2} \mathrm{PO}_{4}\right)$ (Imtiaz et al., 2014). Vanadium is also essential for several species of fungi and nitrogen-fixing microorganisms but there is little evidence whether it is essential for higher plants (Saco et al., 2013).

The role of vanadium in plants is very important during proper growth and development of plants, on the other hand there are many recent reports, which demonstrate the essentiality of $\mathrm{V}$ for plants growth and metabolism (Vachirapatama et al., 2011). However, the adoption of improved agronomic practices, suitable varieties (Madhuri \& PhuleMadhu) and suitable dose of vanadium can increase crop productivity. Ultimately growing suitable varieties with proper dose of vanadium increase growth and yield of crop. Therefore the objectives effect of Vanadium on yield of sweet corn.

\section{Materials and Methods}

The present experiment was undertaken at field of Department of Biological Sciences, Naini Agriculture Institute, Sam Higginbottom University of Agriculture, Technology and Sciences Allahabad, Uttar Pradesh, India during Rabi 2017-18. Sweet corn seeds of hybrid Madhuri and Phulemadhu were used for the pot experiment. Pot experiment was done according to completely randomized design with three replications, and recommended package of practices were followed to raise the crop. Approximately $8 \mathrm{~kg}$ of soil was filled in pot and sowing was done using 3-4 seed per pot by dibbling method. The observation were recorded on each plants of each pot and replication for Number of cob per plant, Cob length $(\mathrm{cm})$, Cob girth $(\mathrm{cm})$, Green cob weight (g/ plant). Sweet corn (30 DAS and flowering time) were allowed to apply Vanadium solution containing seven different Ammonium metavanadate $\left(\mathrm{NH}_{4} \mathrm{VO}_{3}\right)$ concentration: 0, RDF, 20, 40, 60, 80, 100 PPM. The Vanadium solution were maintained a constant volume during the pot experiment. Analysis of variance (ANOVA) as suggested Fisher and Yates (1936) was used to determine the statistical significant of the difference between treatment means in all experiments.

\section{Results and Discussion}

The result in the table 1 indicate that the effect of different concentration of vanadium on same important parameters viz. Number of cob per plant, cob length $(\mathrm{cm})$, cob girth $(\mathrm{cm})$, Green cob weight (g/ plant) in two varieties of sweet corn Madhuri and PhuleMadhu. 
Table.1 Analysis of variance for yield characters of sweet corn

\begin{tabular}{|c|c|c|c|c|c|}
\hline \multirow{3}{*}{$\begin{array}{l}\text { Sr. } \\
\text { No }\end{array}$} & \multirow[t]{3}{*}{ Characters } & \multicolumn{4}{|c|}{ Mean Sum of Squares } \\
\hline & & \multicolumn{2}{|c|}{ Treatments $(\mathrm{df}=7)$} & \multicolumn{2}{|c|}{ Error $(d \mathbf{f}=21)$} \\
\hline & & V1 & V2 & V1 & V2 \\
\hline 1 & Number of cobs & $0.20 * *$ & $0.42 * *$ & 0.09 & 0.04 \\
\hline 2 & Cob length $(\mathrm{cm})$ & $69.18^{* *}$ & $8.33 * *$ & 12.33 & 0.14 \\
\hline 3 & Cob Girth $(\mathbf{c m})$ & $40.15^{* *}$ & $2688 * *$ & 0.56 & 0.51 \\
\hline 4 & Green Cob weight (g/plant $\left.{ }^{-1}\right)$ & $914.23 * *$ & $1363 * *$ & 24.03 & 3.22 \\
\hline
\end{tabular}

Table.2 Mean table of yield character of sweet corn Madhuri

\begin{tabular}{|l|c|c|c|c|}
\hline Treatment & $\begin{array}{l}\text { Number of } \\
\text { Cobs/Plant }\end{array}$ & Cob Length $(\mathbf{c m})$ & Cob Girth $(\mathbf{c m})$ & $\begin{array}{l}\text { Green Cob Weight } \\
\text { (gm/plant) }\end{array}$ \\
\hline Control & 1.00 & 15.23 & 7.23 & 47.43 \\
\hline RDF & 1.00 & 16.57 & 10.40 & 62.57 \\
\hline RDF+V(20 ppm) & 2.00 & 20.33 & 16.13 & 112.57 \\
\hline RDF+V(40ppm) & 1.33 & 18.90 & 14.87 & 93.57 \\
\hline RDF+V(60ppm) & 1.00 & 18.03 & 13.87 & 80.00 \\
\hline RDF+V(80ppm) & 1.00 & 17.27 & 12.80 & 81.63 \\
\hline RDF+V(100ppm) & 1.00 & 16.87 & 11.53 & $\mathbf{8 2 . 0 8}$ \\
\hline Gen. Mean & $\mathbf{1 . 1 9}$ & $\mathbf{1 7 . 6 0}$ & $\mathbf{1 2 . 4 0}$ & 47.43 \\
\hline MIN. & 1.00 & 15.23 & 7.23 & 112.57 \\
\hline MAX. & 2.00 & 20.33 & 16.13 & 2.19 \\
\hline C.V. & 18.33 & 2.13 & 5.80 & 1.04 \\
\hline S.E.M. & 0.13 & 0.22 & 0.42 & 3.15 \\
\hline C.D.5\% & 0.38 & 0.66 & 1.26 & \\
\hline
\end{tabular}

Table.3 Mean table of yield character of sweet corn PhuleMadhu

\begin{tabular}{|l|}
\hline Treatment \\
\hline Control \\
\hline RDF \\
\hline RDF+V(20 ppm) \\
\hline RDF+V(40ppm) \\
\hline RDF+V(60ppm) \\
\hline RDF+V(80ppm) \\
\hline RDF+V(100ppm) \\
\hline Gen. Mean \\
\hline MIN. \\
\hline MAX \\
\hline C.V. \\
\hline S.E.M. \\
\hline C.D. 5\% \\
\hline
\end{tabular}

\begin{tabular}{|c|}
\hline Number of Cobs/plant \\
\hline 1.00 \\
\hline 1.00 \\
\hline 1.67 \\
\hline 1.33 \\
\hline 1.00 \\
\hline 1.00 \\
\hline 1.00 \\
\hline 1.14 \\
\hline 1.00 \\
\hline 1.67 \\
\hline 27.00 \\
\hline 0.18 \\
\hline 0.01 \\
\hline
\end{tabular}

\begin{tabular}{|c|c|}
\hline $\begin{array}{l}\text { Cob Length } \\
\text { (cm) }\end{array}$ & $\begin{array}{l}\text { Cob Girth } \\
\text { (cm) }\end{array}$ \\
\hline 3.40 & 2.47 \\
\hline 8.23 & 5.17 \\
\hline 16.47 & 12.53 \\
\hline 15.73 & 11.50 \\
\hline 14.93 & 10.60 \\
\hline 14.30 & 10.10 \\
\hline 13.93 & 9.73 \\
\hline $\mathbf{1 2 . 4 3}$ & $\mathbf{8 . 8 7}$ \\
\hline 3.40 & 2.47 \\
\hline 16.47 & 12.53 \\
\hline 28.25 & 8.45 \\
\hline 2.03 & 0.43 \\
\hline 6.15 & 1.31 \\
\hline
\end{tabular}

Green Cob Weight (gm/plant)

\begin{tabular}{|c|}
\hline 2.07 \\
\hline 13.77 \\
\hline 48.37 \\
\hline 45.87 \\
\hline 41.27 \\
\hline 39.37 \\
\hline 31.77 \\
\hline $\mathbf{3 1 . 7 8}$ \\
\hline 2.07 \\
\hline 48.37 \\
\hline 15.43 \\
\hline 2.83 \\
\hline 8.59 \\
\hline
\end{tabular}


Data presented in table 2 data shows that for Madhuri variety maximum all parameter was found in $\mathrm{T}_{2}-\mathrm{RDF}+\operatorname{Vanadium}(20 \mathrm{ppm})$ followed by, $\mathrm{T}_{3}-\mathrm{RDF}+\mathrm{V}$ anadium (40 ppm), $\mathrm{T}_{4}-\mathrm{RDF}+$ Vanadium (60 ppm), $\mathrm{T}_{5^{-}} \mathrm{RDF}+$ Vanadium (80 ppm), $\mathrm{T}_{6}-\mathrm{RDF}+$ Vanadium (100ppm), $\mathrm{T}_{1}-\mathrm{RDF}$ and $\mathrm{T}_{0}-$ Control. All treatments showed significant difference in all parameters over control. Data presented in table 3 data shows that for Phulemadhu variety maximum parameter was found in $\mathrm{T}_{2}$ $\mathrm{RDF}+$ Vanadium (20 ppm) followed by $\mathrm{T}_{3}-$ $\mathrm{RDF}+$ Vanadium (100 ppm), $\mathrm{T}_{4}-\mathrm{RDF}+$ Vanadium (40 ppm), $\mathrm{T}_{5}-\mathrm{RDF}+$ Vanadium (60 ppm), $\mathrm{T}_{5}-\mathrm{RDF}+$ Vanadium (80 ppm), $\mathrm{T}_{1}$ - RDF, $\mathrm{T}_{0}$ - Control. All treatments showed significant difference in all parameters over control. Similar finding for plant height, no. leaf, root length, leaf area and yield was observed by Vachirapatama et al., (2011) where he found that low concentration of vanadium increases the plant growth parameters of chines cabbage and tomato. This effect may be due to the fact that $\mathrm{V}$ at this concentration can help increase nitrogen in the form of ammonium compound activating the rice growth Nalewajko et al., (1995). It is also essential for some species of nitrogen fixing bacteria, algae, and fungi. $\mathrm{V}$ plays a pivotal role in the formation of the holo-enzyme of peroxidase of bromine, iodine, and chlorine Hector et al., (2017). Signifying amount of $\mathrm{V}$ in soil water we can shows to have inhibitory effect on plant some enzymes, growth \& photosynthesis Kasim et al., (1999). Similar finding was given by, the obtained result was yield decreases with increases the rate of vanadium because toxicity symptom in roots are club shaped, secondary root number reduction and necrosis Gil et al., (2008). It is the concluded from studies, on vanadium $20 \mathrm{ppm}$ was found as best treatment to increases the yield of sweet corn in pot experiment. The result of current study also indicated that the higher dose of vanadium shows reverse effect on the yield contributing character of the sweet corn.

\section{References}

Adhikary, B. H., Shrestha, J. and RajBaral, B. (2010). Effects of micronutrietns on growth and productivity of maize in acidic soil.International Research Journal of Applied and Basic Sciences, 1(1): 8-15.

Chongkid, B., Vachirapattama, N., and Jirakiattikul, Y. (2007). Effects of vanadium on rice growth and vanadium accumulation in rice tissues kasetsart. Journal of national Agriculture, 41: 2833.

Gil, J., Alvarez, C.E., Martinez, M.C. and Pérez, N. (1994).Effect of vanadium on lettuce growth, cationic nutrition, and yield.Environmental science and engineering, 30(1): 73-87.

Gul, S., Khan, M. H., Khanday, B. A. and Nabi, S. (2015). Effect of sowing methods and npk levels on growth and yield of rainfed maize (Zea mays L.). Hindawi Publishing Corporation Scientific Article ID. 198575: (6).

Hector, E., Trejo-Tellez, L. I., Volke-Haller, V. H., Cadena-Iniguez, J., Garcia, P. S. and Gomez-Merino, C. (2017). Iodine, silicon, and vanadium differentially affect growth, flowering, and quality components of stalks. Sugarcane Sugar Tech, 17-572.

Kasai, M., Yamazak, J.,Kikuchi, M., Iwaya, M. and Sawada, S. (1999). Concentration of vanadium in soil water and its effect on growth and metabolism of rye and wheat plants. Journal of Communications in Soil Science and Plant Analysis, 30(7-8): 971-982.

Khan, W. and Singh, V. (2017). Response of phosphorus application on yield, quality and economics of sweet corn (Zea mays L. saccharata) varieties. Journal of 
Pharmacognosy and phytochemistry. 6(5): 2205-2208.

Meisch, H. U., Benzschawel, H. \& Biella, H. J. (1977).Role of vanadium in green plants. Journal of Archives of Microbiology, 116(1): 91-95.

Muhammad, I., Shuxin, T., Zhijian, X., Han, D., Muhammad, A. and Muhammad S. (2014).Growth, V uptake, and antioxidant enzymes responses of chickpea (Cicer arietinum L.) genotypes under vanadium stress. Plant Soil, 10: 14-41.

Nassrin, S., Mohammad, R. N. and Babak, B. (2012). The effect of microelements spraying on growth, qualitative and quantitative grain corn in Iran. International Research Journal of Applied and Basic Sciences. 3: 27802784.

Painyuli, A., Pal, M. S., Bhatnagar, A. and Bisht, A. S. (2013). Effect of planting techniques and irrigation scheduling on productivity and water use efficiency of sweet corn (Zea mays saccharata). Indian Journal of Agronomy, 58(3): 344-348.
Saco, D., Martín, S. and S. Jose. (2013). Vanadium distribution in roots and leaves of Phaseolus vulgaris morphological and ultra-structural effects. Journal of Biologiaplantarum. 5(1): 128-132.

Singh, U., Saad, A., Chand, T. R., Mir, S. A. and Aga, F. A. (2012). Productivity, economics and nitrogen-use efficiency of sweet corn (Zea mays saccharata.) as influenced by planting geometry and nitrogen fertilization. Indian Journal of Agronomy, 57(1): 43-48.

Suthar, M., Singh, D., Nepalia, V. and Singh A. K. (2014). Performance of sweet corn (Zea mays) varieties under varying fertility levels. Indian Journal of Agronomy, 59(1): 168-170.

Teng, Y., Yang, J., Sun, Z., Wang, J., Zuo, R. and Zheng, J. (2011). Environmental vanadium distribution, mobility and bioaccumulation in different land-use Districts in Panzhihua Region, SW China. Environment Monit Assess, 176: 605-620.

\section{How to cite this article:}

Akshay S. Magar, Pragati Misra, M.B. Latke, Pradeep Kumar Shukla and Ramteke, P.W. 2018. Effect of Different Doses of Vanadium on Yield Attributing Characters of Sweet Corn (Zea mays L.). Int.J.Curr.Microbiol.App.Sci. 7(08): 3097-3101. doi: https://doi.org/10.20546/ijcmas.2018.708.330 